\title{
FEEDING HABITS OF MARINE TUCUXI, SOTALIA FLUVIATILIS, AT CEARÁ STATE, NORTHEASTERN BRAZIL
}

\author{
Lívio Moreira de Gurjão ${ }^{1, *}$, Manuel Antônio de Andrade Furtado Neto ${ }^{2}$ \\ Roberta Aguiar dos Santos ${ }^{3}$ and Paulo Cascon ${ }^{4}$
}

The marine tucuxi, Sotalia fluviatilis (Gervais, 1853), is one of the smallest cetaceans known, with the maximum length of $2.2 \mathrm{~m}$ (Jefferson et al., 1993), and is described as having coastal habits and a continuous distribution along most part of the Brazilian coast (Borobia et al., 1991).

According to the 2002 IUCN Red List of Threatened Species (IUCN, 2002), S. fluviatilis is classified as a Data Deficient (DD) species. In Brazil, marine tucuxi has been frequently by-caught in fishing activities along the northeastern coast (Siciliano, 1994). Monteiro-Neto et al. (2000) reported the death of 76 individuals in Ceará State, which were found stranded or entangled in fishing nets from January 1992 to December 1998.

Stomach contents analysis is a very useful and trusting tool to determine the species ingested by cetaceans (Barros and Wells, 1998). Recent works have reported the diet contents of marine mammals in Brazil (Ott, 1994; Bassoi, 1997; Di Beneditto et al., 2001a; Di Beneditto et al., 2001b), which can provide valuable information about different aspects of cetacean biology.

In order to assess feeding habits of marine tucuxi in Ceará State, stomachs from 26 S. fluviatilis specimens were collected from 1992 to 2000 and were deposited at the Associação de Pesquisa e Preservação de Ecossistemas Aquáticos (AQUASIS) collection. The animals were captured in fishing nets or stranded along four different beaches from Ceará State (Figure 1).

Food items were retrieved from the proximal esophagus to the distal pyloric stomach. The recovered material was passed through a $1.0 \mathrm{~mm}$-mesh sieve, carefully washed in current water and then stored in a $70 \%$ ethanol solution. Subsequently, stomach contents were individually spread on a tray, where traced (otoliths and cephalopod beaks) and non-traced items were separated (Gannon et al., 1997a). Analysis of trace items was conducted in order to address biases caused by differential rates of digestion.

A reference collection of otoliths, deposited at the Grupo de Ictiologia Marinha Tropical (IMAT)/Departamento de Engenharia de Pesca/Universidade Federal do Ceará (UFC), was used to identify ingested bony fishes. The identification key for otoliths proposed by Bastos (1990) was also used in this study.

Cephalopod beaks were used to identify and quantify cephalopods consumed by marine tucuxi, following Clarke (1986), Haimovici et al. (1994), and Sweeney and Roper (1998), and had their mantle length (ML) estimated through regression equations.

Non-traced prey were identified following Figueiredo and Menezes $(1978,1980)$, Menezes and Figueiredo (1980, 1985), Cervigón (1989, 1993, 1994, 1996), Freitas (1996) and Ruppert and Barnes (1996), and then measured and stored as previously described.

Prey items had their frequency of occurrence (FO) and numerical abundance (\%num) analysed according to Gannon et al. (1997b).

In addition, the relationship between type of fishing gear and by-catch of dolphins was assessed through interviews with fishermen and the monitoring of fishing activities.

Dolphins collected are listed in Table 1. Four of the 26 samples were directly removed from fishing nets. Specimens 101214 and 101235 were found dead, entangled in gill nets for scombrids (mackerels) and carangids (jacks). Individuals 101251 and 101166 were captured in $60 \mathrm{~m}$-long $\times 2 \mathrm{~m}$-high bottom-set nets for lobster fishery. The other tucuxi specimens were found stranded and some of them had net scars and/or mutilation marks.

Solid food items were recorded in 25 stomachs and in one animal (101251) the stomach was empty. So, one dolphin was excluded from stomach content analyses.

Three prey categories (fishes, mollusks and crustaceans) were found in the stomach contents analysed (Table 2). We identified eight different families of Teleostei and two families of cephalopods. Crustaceans, represented by ten small shrimp and one crab, could not be identified beyond the level of order (Decapoda), neither precisely measured due to the damage caused by digestion.

We recovered a total of 573 otoliths from the 25 stomachs, which means that at least 287 fishes, besides the identified Teleostei, were eaten. Among these otoliths, we possibly identified 8 gerreids, 6 haemulids (Pomadasys corvinaeformis), 6 mullids and 1 sciaenid (Larimus breviceps). We did not include these findings among in Table 2, because we are not sure about the identification of some taxa and we have no regression equation in order to estimate their total length.

\footnotetext{
${ }^{1}$ Universidade Federal do Ceará, Departamento de Engenharia de Pesca, Mestrado em Engenharia de Pesca. Bloco 827, Campus do Pici, Fortaleza, CE, 60035-000, Brazil. E-mail: livgurjao@yahoo.com.

${ }^{2}$ Universidade Federal do Ceará, Departamento de Engenharia de Pesca, Biomol-Lab/Elace. Bloco 827, Campus do Pici, Fortaleza, CE, 60035-000, Brazil. E-mail: mfurtado98@hotmail.com.

${ }^{3}$ Fundação Universidade do Rio Grande, Departamento de Oceanografia. Caixa Postal 474, Rio Grande, RS, 96201-900, Brazil. E-mail: posras@super.furg.br.

${ }^{4}$ Universidade Federal do Ceará, Departamento de Biologia, Laboratório de Zoologia. Bloco 909, Campus do Pici, Fortaleza, CE, 60451-970, Brazil. E-mail: pc@ufc.br.

*Corresponding author: Rua Paula Ney, 155/500, Aldeota, Fortaleza, CE, 60140-200, Brazil. Phone/fax number: (85) 261 6611. E-mail: livgurjao@yahoo.com
} 


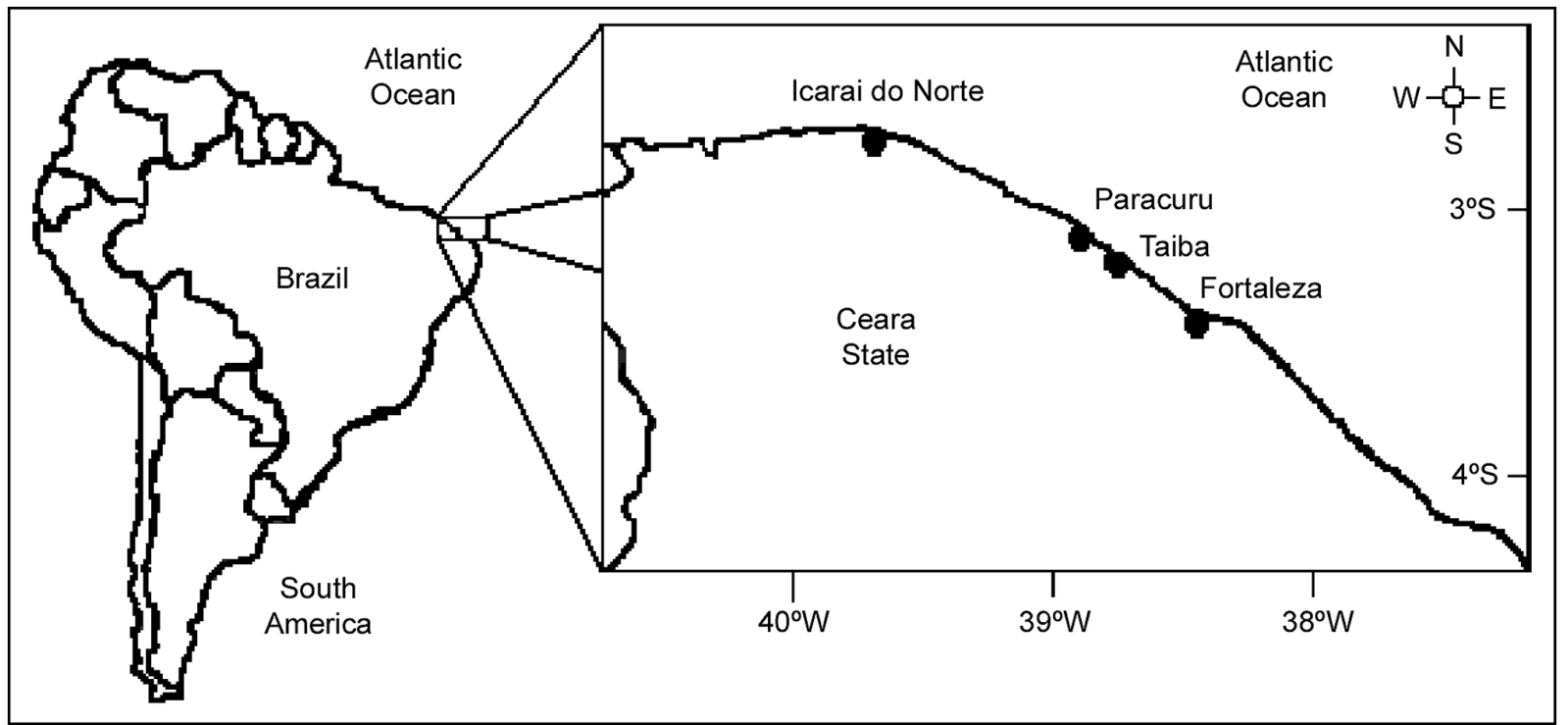

Figure 1. Map of Ceará State, Brazil, showing the collection sites of the S. fluviatilis specimens.

Table 1. Data from 26 S. fluviatilis specimens collected in Ceará.

\begin{tabular}{|c|c|c|c|c|}
\hline DOLPHIN IDENTIFICATION NUMBER & SEX & TOTAL LENGTH $(\mathrm{m})$ & COLLECTION SITE & COLLECTION DATE \\
\hline $10127^{\mathrm{NS}, \mathrm{MM}}$ & 우 & 1.77 & Fortaleza & 11 September 1992 \\
\hline Ind. & Ind. & Ind. & Ind. & 1993 \\
\hline 101018 & Ind. & Ind. & Taíba & ? August 1994 \\
\hline Ind. & Ind. & Ind. & Ind. & ? December 1994 \\
\hline $101131^{\mathrm{NS}, \mathrm{MM}}$ & $0^{\prime}$ & 1.87 & Fortaleza & 19 January 1995 \\
\hline 101223 & 오 & 2.00 & Fortaleza & 11 December 1995 \\
\hline 101232 NS & 우 & 1.28 & Fortaleza & 26 January 1996 \\
\hline Ind. & Ind. & Ind. & Ind. & 3 May 1996 \\
\hline $101214^{\mathrm{NS}, *}$ & ㅇ & 1.28 & Taíba & 9 June 1996 \\
\hline $101143^{\text {MM }}$ & $\sigma^{\prime}$ & 1.78 & Taíba & 22 June 1996 \\
\hline $101150^{\text {NS }}$ & $\sigma^{*}$ & 1.89 & Taíba & 23 June 1996 \\
\hline $101235^{\mathrm{NS}, *}$ & 오 & 1.82 & Fortaleza & 1 July 1996 \\
\hline 101137 мM & $\sigma^{\prime}$ & 1.65 & Icaraí do Norte & Ind. \\
\hline $101251^{\mathrm{NS}, *}$ & 우 & 0.96 & Taíba & 8 October 1996 \\
\hline $101152^{\mathrm{MM}}$ & $\sigma^{\prime \prime}$ & 1.64 & Fortaleza & 9 October 1996 \\
\hline $101166^{\mathrm{NS}, *}$ & $\sigma^{\prime}$ & 1.38 & Fortaleza & 31 July 1997 \\
\hline $101264^{\mathrm{NS}, \mathrm{MM}}$ & 우 & 1.81 & Fortaleza & 8 October 1997 \\
\hline $101267^{\text {NS }}$ & 오 & 1.35 & Fortaleza & 16 January 1998 \\
\hline $101268^{\mathrm{NS}, \mathrm{MM}}$ & 우 & 2.00 & Fortaleza & 21 February 1998 \\
\hline 101273 & 우 & 1.85 & Fortaleza & 2 August 1998 \\
\hline $101280 \mathrm{MM}$ & 우 & 1.66 & Fortaleza & 7 February 1999 \\
\hline 101284 & 오 & 1.92 & Taíba & 24 July 1999 \\
\hline $101185^{\mathrm{NS}, \mathrm{MM}}$ & $\sigma^{\circ}$ & 1.69 & Fortaleza & 5 August 1999 \\
\hline $101287^{\text {MM }}$ & 우 & 1.56 & Fortaleza & 30 September 1999 \\
\hline 101188 NS & $\sigma^{\prime}$ & 1.64 & Fortaleza & 7 July 1999 \\
\hline $1011944^{N S}$ & $\sigma^{\prime \prime}$ & 1.72 & Paracuru & 24 June 2000 \\
\hline
\end{tabular}

(NS) net scars, (MM) mutilation marks, $\left(^{*}\right)$ removed directly from fishing nets, (Ind) indetermined. 
The occurrence of fishes, mollusks and crustaceans in stomachs from the $S$. fluviatilis specimens agrees with the prey categories described in the literature as components of the diet of marine tucuxi (Silva and Best, 1996; Di Beneditto, 2000).

Fishes from the families Gerreidae, Haemulidae, Ophichthidae and Sciaenidae have already been cited as prey of S. fluviatilis (Borobia and Barros, 1989; Barros and Teixeira, 1994; Oliveira et al., 1998). However, we could not find any previous records of the presence of the fish families Dactylopteridae, Gobiidae, Mullidae and Scaridae in the diet of the marine tucuxi. Several other families of Teleostei have previously been cited in stomach contents of $S$. fluviatilis, such as Ariidae, Centropomidae, Clupeidae, Congridae Engraulidae, Batrachoididae, Mugilidae, Paralichthidae, Serranidae, Stromateidae and Trichiuridae (Di Beneditto et al., 1998; Oliveira et al., 1998; Santos et al., 2002), but these were not recorded in this study.

Fishes identified in stomachs of marine tucuxi in the present work are commonly found in shallow waters of coastal environments. These also have a strong association with the bottom, either by having benthic habits or by being mid-water fishes which frequently feed on the bottom (Figueiredo and Menezes, 1978, 1980; Menezes and Figueiredo, 1980, 1985). In addition, almost all these fish groups are encountered in both sandstone reefs from intertidal zones and estuaries in Ceará State (Araújo et al., 2000a; Araújo et al., 2000b). Hence, a coastal distribution of $S$. fluviatilis in Ceará State is inferred based on the habits and habitats of ingested fishes, as wells as the possible usage of sandstone reefs and estuarine areas for foraging. In Ceará State, the same distribution for marine tucuxi was cited before (Oliveira et al., 1995; Monteiro-Neto et al., 2000). Also, the utilization of estuaries by marine tucuxi has already been reported (Reis et al., 1998). Borobia et al. (1991) suggested that the close association of marine tucuxis to estuaries might be related to physiological constraints.

Just demersal bony fishes were found in stomachs of $S$. fluviatilis in the present work, what suggest that in Ceará State marine tucuxi can dive near the bottom during feeding. This statement agrees with what was found by many authors, who have recorded the presence of both surface and demersal fishes in stomachs of marine tucuxi from elsewhere in Brazilian waters (Barros and Teixeira, 1994; Silva and Best, 1996; Santos et al., 2002) and suggested that $S$. fluviatilis can feed in different water depths (Borobia and Barros, 1989).

Regarding the cephalopods identified in this study, Lolliguncula brevis, Loligo plei and L. sanpaulensis have already been noted as prey of tucuxi (Santos and Haimovici, 2001; Di Beneditto 2000; Santos et al., 2002); however, no previous records of Octopus sp. in the stomachs of $S$. fluviatilis were found. These cephalopods occur in neritic environments and are commonly captured in beach seines performed in Mucuripe inlet, in Fortaleza, Ceará state (Freitas, 1996). Octopus sp. has benthic habits
(Ruppert and Barnes, 1996), while L. brevis is commonly classified as an estuarine associated species (Borobia and Barros, 1989). L. plei is thought to have a more pelagic distribution when compared to the other squid species listed in this study (Ropper et al., 1984). The occurrence of these cephalopods in the marine tucuxi stomachs, also suggest that the tucuxi has a coastal distribution in Ceará state and possibly feed near the bottom in estuarine waters. Though it was not possible to further identify the ingested decapods, we noted that shrimp were much more abundant than crab. The occurrence of crustaceans in stomachs of tucuxis has previously been recorded, including the presence of penaeid shrimp (Oliveira et al., 1998; Santos et al., 2002). Di Beneditto (2000) reported that crustaceans were less representative than other prey items in stomach contents of marine S. fluviatilis, what agrees with our findings in this work (Table 2).

FO and \%num analysis revealed fishes as being the most important prey category on the diet of marine $S$. fluviatilis, followed by mollusks and crustaceans (Table 2). Reis et al. (1998) reached similar conclusions studying five stomachs of marine tucuxi, in Bahia State, Brazil. According to our findings, both criteria also point families Gerreidae and Mullidae as being very representative on marine tucuxi diet. In other Brazilian States, some authors noted that clupeids (Pellona harroweri), trichiurids (Trichiurus lepturus), batrachoidids (Porichthys porosissimus) and sciaenids (Stellifer sp.) were frequent in stomach contents of marine tucuxi (Borobia and Barros, 1989; Barros and Teixeira, 1994; Di Beneditto, 2000), however the presence of gerreids (mojarras) was also common (Reis et al., 1998; Santos et al., 2002). L. plei appeared to be the most frequent and abundant species, compared to other cephalopods, when FO and \%num are analysed. Borobia and Barros (1989) also found more Loligo sp. specimens in stomachs of marine $S$. fluviatilis than L. brevis.

The results obtained here suggest that marine tucuxi might have being threatened by the artisanal fishery performed in Ceará State, according to interviews with fishermen and the monitoring fishing boats for their fish landings. Fish groups such as gerreids, haemulids, mullids, scarids and sciaenids are commonly captured by gill nets for further commercialization in Mucuripe inlet, where most of the dolphins were by-caught. This is an indication of possible competition between tucuxi and fishermen for similar resources, which might explain entanglement of these cetaceans in gill nets. The fact that individuals 101214 and 101235 were found entangled in this kind of fishing gear supports this statement (Table 1 ).

Another threat to tucuxi in Ceará are bottom nets for lobster fishery which are also non-selective, capturing at least 30 different families of fishes, including Gerreidae, Haemulidae, Mullidae and Scaridae (Ivo et al., 2000). This suggests that, when searching for food, tucuxi can incidentally be entangled in those nets. Evidence of by catch in this fishery is shown by the two individuals (101251 and 101166) directly removed from bottom-set nets for lobster fishery in the present work (Table 1). 
Table 2. Prey items identified in stomachs from 25 S. fluviatilis specimens.

\begin{tabular}{|c|c|c|c|c|}
\hline PREY & $\mathrm{N}$ & $\begin{array}{c}\text { MEAN TOTAL LENGTH }(\mathrm{mm}) \\
\{\text { STANDARD ERROR }(\mathrm{mm})\} \\
{[\text { RANGE }(\mathrm{mm})]} \\
\end{array}$ & $\mathrm{FO}(\%)$ & $\% \operatorname{NUM}(\%)$ \\
\hline Bony fishes & $\underline{328}$ & - & $\underline{100}$ & $\underline{64.1}$ \\
\hline Gerreidae & 12 & $127.6\{32.5\}[83.6-112.8]$ & 24 & 2.3 \\
\hline \multicolumn{5}{|l|}{ Diapterus olistostomus (5) } \\
\hline \multicolumn{5}{|l|}{ Diapterus sp. (2) } \\
\hline \multicolumn{5}{|l|}{ Eucinostomus sp. (5) } \\
\hline Mullidae & 10 & $136.1\{7.2\}[134.9-157.9]$ & 16 & 2.0 \\
\hline \multicolumn{5}{|l|}{ Pseudopeneus maculatus (10) } \\
\hline Haemulidae & 3 & $123.5\{27.6\}[97.4-164.9]$ & 12 & 0.6 \\
\hline \multicolumn{5}{|l|}{ Pomadasys corvinaeformis (3) } \\
\hline Ophichthidae & 4 & $271.8\{113.5\}[156.1-406.0]$ & 8 & 0.8 \\
\hline \multicolumn{5}{|l|}{ Myrichthys ocellacus (1) } \\
\hline \multicolumn{5}{|l|}{ Unidentified ophichthids (3) } \\
\hline Scaridae & 3 & $203.5\{23.7\}[174.8-239.1]$ & 4 & 0.6 \\
\hline Gobiidae? & 7 & $90.3\{11.9\}[61.7-112.0]$ & 4 & 1.4 \\
\hline Dactylopteridae & 1 & 220.4 & 4 & 0.2 \\
\hline \multicolumn{5}{|l|}{ Dactylopterus volitans (1) } \\
\hline Sciaenidae & 1 & 157.0 & 4 & 0.2 \\
\hline Other fishes & 287 (at least) & - & 88 & 56.0 \\
\hline \multicolumn{5}{|l|}{ Otoliths (573) } \\
\hline$\underline{\text { Mollusks }}$ & $\underline{173}$ & - & $\underline{40}$ & $\underline{33.8}$ \\
\hline Loliginidae & 128 & - & 36 & 25.0 \\
\hline Loligo plei (83) & & $100.9\{34.7\}[41.2-196.3]^{*}$ & & \\
\hline Lolliguncula brevis (21) & & $47.6\{5.8\}[27.6-62.2]^{*}$ & & \\
\hline Unidentified loliginids (24) & & - & & \\
\hline Octopodinae & 45 & $91.8\{19.0\}[37.3-143.9]^{*}$ & 16 & 8.8 \\
\hline Octopus sp. (42) & & $95.4\{20.0\}[55.5-143.9]^{*}$ & & \\
\hline Unidentified octopuses (3) & & $41.6\{4.3\}[37.3-45.9]$ & & \\
\hline Decapod Crustaceans & $\underline{11}$ & - & $\underline{8}$ & $\underline{2.2}$ \\
\hline Shrimp & 10 & - & 8 & 2.0 \\
\hline Crab & 1 & - & 4 & 0.2 \\
\hline
\end{tabular}

$\left(^{*}\right)$ for traced mollusks, mantle length was estimated through regression equations. 


\section{Acknowledgments}

We thank the Associação de Pesquisa e Preservação de Ecossistemas Aquáticos (AQUASIS) for the collection of stomachs analysed in the present work, in particular Cristine Negrão, who helped collect most of the stomach contents studied here. Dr. Nélio B. Barros from Mote Marine Laboratory gave information about otoliths and, with an anonymous referee, made helpful and important suggestions on this manuscript. Dr. Maria Elisabeth Araújo (UFPE) helped to set the reference collection of otoliths and Dr. Ana Paula Di Beneditto (UENF) gently sent one of her articles, which helped us a lot.

\section{References}

Araújo, M.E., Cunha, F.E.A., Carvalho, R.A.A., Freitas, J.E.P., Nottingham, M.C. and Barros, B.M.N. (2000a) Ictiofauna marinha do estado do Ceará, Brasil: II. Elasmobranchii e Actinopterygii de arrecifes de arenito da região entre marés. Arquivo de Ciências do Mar 33: 133-138.

Araújo, M.E., Teixeira, J.M. and Oliveira, A.M.E. (2000b) Ictiofauna marinha do estado do Ceará, Brasil: III. Actinopterygii de estuários. Arquivo de Ciências do Mar 33: 139-142.

Barros, N.B. and Texeira, R.L. (1994) Incidental catch of marine tucuxi, Sotalia fluviatilis, in Alagoas, northeastern Brazil. Report of the International Whaling Commission (special issue 15): 265-268

Barros, N.B. and Wells, R.S. (1998) Prey and feeding patterns of resident bottlenose dolphins (Tursiops truncatus) in Sarasota Bay, Florida. Journal of Mammalogy 79(3): 1045-1059.

Bassoi, M. (1997) Avaliação da dieta de toninhas, Pontoporia blainvillei (Gervais \& D'Orbigny, 1844), capturadas acidentalmente na pesca costeira de emalhe, no sul do Rio Grande do Sul. B Sc, Oceanologia, FURG, Rio Grande, 68p.

Bastos, G.C.C. (1990) Morfologia de otólitos da algumas espécies perciformes (Teleostei) da costa sudeste-sul do Brasil. Master Thesis, Instituto Oceanográfico da Universidade de São Paulo, IOUSP, São Paulo, 180p.

Borobia, M. and Barros, N.B. (1989) Notes on the diet of marine Sotalia fluviatilis. Marine Mammal Science 5(4): 395-399.

Borobia, M., Siciliano, S., Lodi, L. and Hoek, W. (1991) Distribution of the south american dolphin Sotalia fluviatilis. Canadian Journal of Zoology 69: 1025-1039.

Cervigón, F. (1989) Los peces marinos de Venezuela. Fundación Científicas Los Roques, Caracas, Venezuela, v.1.

Cervigón, F. (1993) Los peces marinos de Venezuela. Fundación Científicas Los Roques, Caracas, Venezuela, v.2.

Cervigón, F. (1994) Los peces marinos de Venezuela. Fundación Científicas Los Roques, Caracas, Venezuela, v.3.

Cervigón, F. (1996) Los peces marinos de Venezuela. Fundación Científicas Los Roques, Caracas, Venezuela, v. 4.

Clarke, M.R. (1986) A handbook for the identification of cephalopod beaks. Clarendon Press, Oxford, U.K.

Di Beneditto, A.P.M. (2000) Ecologia alimentar de Pontoporia blainvillei $e$ Sotalia fluviatilis (Cetacea) na costa Norte do Estado do Rio de Janeiro, Brasil. Tese de doutorado, Universidade Estadual Norte Fluminense, UENF, Rio de Janeiro, 195p.

Di Beneditto, A.P., Ramos, R., Lima, N.R. and Santos, R.A. (1998) Feeding ecology of Pontoporia blainvillei and Sotalia fluviatilis in northern Rio de Janeiro, Brazil: a preliminary analysis. Page 66 in Abstracts, VIII Reunião de Trabalho de Especialistas em Mamíferos Aquáticos da América do Sul and II Congresso da Sociedade Latinoamericana de Especialistas em Mamíferos Aquáticos, 25-29 October, Olinda, Brasil.
Di Beneditto, A.P., Ramos, R. and Lima, N.R.W. (2001a). Os golfinhos: origem, classificação, captura acidental, hábito alimentar. Ed. Cinco Continentes, Porto Alegre, Brasi1.

Di Beneditto, A.P., Ramos, R., Siciliano, S., Santos, R.A., Bastos, G.C. and Fagundes Netto, E.B. (2001b) Stomach contents of delphinids from Rio de Janeiro, Southeastern Brazil. Aquatic Mammals 27(1): 24-28.

Figueiredo, J.L. and Menezes, N.A. (1978) Manual de peixes marinhos do sudeste do Brasil. II. Teleostei (1). Museu de Zoologia. Universidade de São Paulo, São Paulo, Brasil.

Figueiredo, J.L. and Menezes, N.A. (1980) Manual de peixes marinhos do sudeste do Brasil. III. Teleostei (2). Museu de Zoologia. Universidade de São Paulo, São Paulo, Brasil.

Freitas, J.R. (1996) Aspectos bioecológicos dos cefalópodes que ocorrem nos arrastos-de-praia na enseada do Mucuripe, Fortaleza-Ceará. B Sc, Departamento de Biologia, Universidade Federal do Ceará, Fortaleza, Brasil, 72p.

Gannon, D.P., Read, A.J., Craddock J.E., Fristrup, K.M. and Nicolas, J.R. (1997a) Feeding ecology of long-finned pilot whales Globicephala melas in the western North Atlantic. Marine Ecology Progress Series 148: 1-10.

Gannon, D.P., Read, A.J., Craddock J.E. and Mead. J.G. (1997b) Stomach contents of Long-Finned Pilot Whales (Globicephala melas) stranded on the U.S. Mid-Atlantic coast. Marine Mammal Sciences 13(3): 405-418.

Haimovici, M., Perez, J.A.A. and Santos, R.A. (1994) Class Cephalopoda Cuvier, 1797. Pages 311-320 + plates in Rios, E.C. (Ed.), Seashells of Brazil, $2^{\text {nd }}$ Edition. Editora da FURG, Rio Grande, Brasil.

IUCN. 2002 IUCN Red List of Threatened Species. http:// www.redlist.org.

Ivo, C.T.C., Santiago, M.E. and Monteiro Neto, C. (1996) Fauna acompanhante na pesca das lagostas Panulirus argus (Latreille) e Panulirus laevicauda (Latreille), no estado do Ceará, Brasil. Arquivo de Ciências do Mar 30(1-2): 41-47.

Jefferson, T.A., Leatherwood, S. and Webber, M.A. (1993) Marine mammals of the world. Ed. FAO, Rome.

Menezes, N.A. and Figueiredo, J.L. (1980) Manual de peixes marinhos do sudeste do Brasil. IV. Teleostei (3). Museu de Zoologia, Universidade de São Paulo, São Paulo, Brasil.

Menezes, N.A. and Figueiredo, J.L. (1985) Manual de peixes marinhos do sudeste do Brasil. V. Teleostei (4). Museu de Zoologia, Universidade de São Paulo, São Paulo, Brasil.

Monteiro Neto, C., Alves Júnior, T.T., Ávila, F.J.C., Campos, A.A., Costa, A. F., Silva, C.P.N. and Furtado Neto, M.A.A. (2000) Impact of fisheries on the tucuxi (Sotalia fluviatilis) and rough-toothed dolphin (Steno bredanensis) populations off Ceará state, northeastern Brazil. Aquatic Mammals 26(1): 49-56.

Oliveira M.R., Pinheiro, P.C. and Rosas, F.C.W. (1998) Ecologia alimentar de Sotalia fluviatilis e Pontoporia blainvillei acidentalmente capturados no litoral do Paraná. Page 145 in Abstracts, VIII Reunião de Trabalho de Especialistas em Mamíferos Aquáticos da América do Sul and II Congresso da Sociedade Latinoamericana de Especialistas em Mamíferos Aquáticos, 25-29 October, Olinda, Brasil.

Ott, P.H. (1994) Estudo da ecologia alimentar de Pontoporia blainvillei (Gervais \& D'Orbigny, 1844) (Cetacea, Pontoporiidae) no litoral Norte do Rio Grande do Sul, Sul do Brasil. Ciências Biológicas, UFRGS, Porto Alegre, 69p.

Reis, M.S.S., Reis, L.W.D., Lima, F., Baracho, C. and Jorge, A. (1998). Nota preliminar sobre a dieta alimentar do boto Sotalia fluviatilis Gervais, 1853 (Cetacea, Delphinidae) no litoral do estado da Bahia. Page 173 in Abstracts, VIII Reunião de Trabalho de Especialistas em Mamíferos Aquáticos da América do Sul and II Congresso da Sociedade Latinoamericana de Especialistas em Mamíferos Aquáticos, 25-29 October, Olinda, Brasil. 
Roper, C.F.E., Sweeney, M.J. and Nauen, C.E. (1984) FAO Species Catalogue (Vol. 3) - Cephalopods of the World. Ed. FAO, Rome.

Ruppert, E.E. and Barnes, R.D. (1996) Zoologia dos invertebrados. $6^{\text {th }}$ edition. Saunders College Publishing/Editora Roca LTDA, São Paulo, Brasil.

Santos, R.A. and Haimovici, M. (2001) Cephalopods in the diet of marine mammals stranded or incidentally caught along southeastern and southern Brazil (21-34 S). Fisheries Research, 52: 99-112.

Santos M.C.O., Rosso, S., Santos, R.A., Lucato, S.H.B. and Bassoi, M. (2002) Insights on small cetacean feeding habits in southeastern Brazil. Aquatic Mammals 28(1): 38-45.
Siciliano, S. (1994) Review of small cetaceans and fishery interactions in coastal waters of Brazil. Report of the International Whaling Commission 15: 241-250.

Silva, V.M.F. and Best, R.C. (1996) Sotalia fluviatilis. American Society of Mammalogists. Mammalian Species. 527: 1-7.

Sweeney, M.J. and Roper, C.F.E. (1998) Classification, type localities, and type repositories of recent Cephalopoda. Pages 561-599 in Voss, N.A., Vecchione, M., Toll, R.B and, Sweeney, M.J. (Eds) Systematics and biogeography of cephalopods, Part II. Smithsonian Contribution to Zoology, v.586. 